caused to the façade of the monumental church of St. Anna, one of the oldest in Sicily ; some damage has been done to the Cathedral, and cracks have appeared in many walls of the poorer type of building. Two people have been killed by falling masonry and twenty-five injured. The electricity supply was temporarily out of action. The earthquake was the most severe for many years, and alarm was caused especially amongst children and people in the poorer quarters of the city. According to a Times message, the epicentre of the shock is estimated to have been between Palermo and the islands of Ustica and Alicudi to the north-north-west of Palermo, which would be approximately $38 \cdot 5^{\circ} \mathrm{N}$., $13 \cdot 25^{\circ} \mathrm{E}$. This is in a relatively highly active region seismically, and earthquakes occurred near to this epicentre on August 17, 1926 (38.5 $5^{\circ}$ N., $15^{\circ}$ E.) and August 21, 1930 (39 N., $14.5^{\circ} \mathrm{E}$.). The great Messina earthquake of December 28, 1908, which has been described by Davison, affected this area, according to Baratta, though the epicentre was, of course, somewhat to the east of the present one.

From 1.30 a.m. on January 17, and continuing for three hours at intervals, Paris experienced earth tremors so slight that they were not felt by anyone. The tremors were recorded on the seismographs at the Paris Observatory.

\section{Native Races and Tuberculosis}

Some interesting data bearing upon recent theory of the racial incidence of disease are brought together and discussed in relation to tuberculosis in the Lancet of January 13. The older view ascribed the apparently selective action of the infection on native races mainly to innate biological differences, but there is now a tendency to emphasize work and living conditions- - with the consequent risk of intense exposure and deficient resistance-on one hand, and the factor of bacteriological immunity on the other. Thus a recent view is quoted in which there is represented a balance between heredity and environment. The emphasis now being laid on social factors, it is suggested, opposes the defeatist attitude that native races are just 'different', and indicates lines of action within human control.

In support of this view, attention is directed to the situation at present in India and Africa. On the Rand, although the incidence among natives working in the mines has fallen considerably in recent years, the incidence among natives in the Union has probably fallen little, if at all. All cases discovered in the mines are repatriated at once and the majority are dead in two years. Thus there is a continuous stream of infectious men returning to the territories from which are derived a return stream of new recruits. There are no sanatoria and little provision of public medical service. In India, a similar situation has arken in the interchange between urban and rural areas which the growth of industrialism and transport facilities has made possible, with the result that Bengal alone is said to have a million cases of tuberculosis and a hundred thousand deaths annually.
Analysis of the data of the incidence of tuberculosis among non-European or primitives would seem to justify the contention that the problem is now most serious where native agricultural populations are becoming industrialized. That the situation is remediable is indicated by the situation under the Russian Soviets, where rapid industrialization has been accompanied by expansion of the tuberculosis services, with the result that there has been a notable decline in tuberculosis mortality. The writer in the Lancet concludes with the admonition that it is the white man's responsibility that the situation in the British Empire should be squarely faced.

\section{Mental Disease in Peru}

IN a recent paper (Amer. J. Psychiat., 96, 403 ; 1939) Dr. Horatio M. Pollock states that the care of the mentally sick in Peru has gone through a series of progressive stages similar to that in the development of psychiatric science in the United States. A long period of neglect was succeeded by one of inadequate care in almshouses or asylums, which in turn was followed by so-called hospital care with some degree of medical attention, and finally scientific treatment in a modern hospital. The first hospital treatment for mental patients in Peru was provided in the seventeenth century in two general hospitals at Lima, one being St. Andrew's Hospital for men and the other the St. Anne's Hospital for women. Towards the middle of the nineteenth century the special section in the St. Andrew's Hospital betame an independent unit with a special physician to look after the patients, and in 1859 a new building named "Hospital de la Misericordia" for mental patients was opened in the outskirts of Lima with accommodation for 160 patients. It was divided into four sections, respectively for quiet cases, those periodically disturbed, mental defectives and epileptics, and violent cases.

In 1918 an entirely new hospital for mental patients, which was named after its benefactor Victor Larco Herrera, was opened at Magdalena del Mare about four miles from Lima with aceommodation for more than a thousand patients. The treatment in this hospital has been modernized, and at the present time compares favourably, according to Dr. Pollock, with that in many hospitals in the United States. A single hospital, however, is not sufficient for all the persons requiring mental treatment in Peru. At least two more are needed, and funds are not yet available for enlargement of the present building.

\section{Higher Education in Malaya}

"Higher Education in Mataya" (H.M. Stationery Office, $2 s .6 d$.) is a thorough and most valuable survey. It includes the whole background of teaching and adds an able summary of the resources of the country, mainly due to the rubber plant, and the variety of its population, Chinese, Indians and Malays. The last-named have only been under Western civilization for $60-70$ years. They do not dwell in towns like the Chinese. Raffles College, opened in 1928 , is the main centre of advanced education, and is 
increasingly appreciated by parents, who recognize the value of its teaching. One of the difficulties is that English is learnt as a foreign language; so that subject can scarcely be taken, as at the University of London, with Middle English and Anglo-Saxon as necessary adjuncts. It would be like studying Latin in early and medieval sources as well as Virgil and Cicero. The Commissioners urge that the standard of the London degree should be attempted and some modification of the English course allowed, tending to special knowledge of English masterpieces.

The present diploma of the College is not recognized outside Malaya, and not much progress can be achieved without some external assistance in the examinations, which could be managed by the use of air-mail. The professors take leave once in three years, which puts rather a heavy burden on their substitutes, but gives them a chance to meet external examiners. The present arrangements for a president are inadequate, and the "high wastage rate" of failures needs to be reduced. Several drastic improvements are suggested. We regret to notice that science teaching in the schools is generally in a very backward state, and biology has been scarcely begun. The King Edward VII College of Medicine at Singapore is well equipped and does good work within its limits; but it needs a larger scope, particularly regarding public health.

\section{International Journal of Agrarian Affairs}

THE first International Conference of Agricultural Ecompmists was held ten years ago. As the period elapsing between meetings is now three years, some means of maintaining an interchange of ideas, beyond the issue of the proceedings, seemed desirable. The International Journal of Agrarian Affairs, the first number of which has just been published, is a bold attempt to meet this need. Two numbers will be brought out each year, the intention being to develop a series of studies on economic and social problems, one such problem being dealt with at a time. The Journal will therefore serve as a complement rather than an addition to the statistical year-books of agricultural information which are already available. The kind of topics which will form the subject-matter are those common to all countries, and the aim will be to emphasize the universal concern with the solution of such problems, and to discuss them from all possible angles.

The first number deals with the problem of surplus agricultural population. Contributions are made from such widely different localities as Harvard University, Edinburgh, Washington, Quebec, Sofia and Riga. The theoretical basis of the problem is first discussed and an account given of the historical influence of landowning. Other writers stress the effect of policies of restriction on trade and on movements of population between countries, and describe the special problems of Bulgaria and Latvia, while as regards remedies the development of subsistence holdings is advocated. Though not actually the official organ of the International C'onference of Agricultural Econom- ists, the Journal will be issued free to all members. For non-members the price is $3 s$. $6 d$, or $£ 1$ per volume of six numbers (including postage). All subscriptions and communications should be addressed to the Editor, 3 Magpie Lane, Oxford.

\section{Meteorology in Iraq}

The third annual report of the Director of the Meteorological Service of the Government of Iraq, which covers the year ending March 31,1939 , shows that, owing to the difficulty of obtaining the necessary staff, the basic organization of the Service had not been completed by that date. For example, although new offices were available at Nasiriya and Diwaniya, no staff was available to man them. At the headquarters station at Baghdad, continuous records of wind, temperature, humidity and rainfall were maintained and were analysed and published in the Monthly Weather Report. Upper winds were measured three times a day, and the results appeared in the I.C.A.N. summaries published by the Meteorological Office, London, up to December 1938. After that month they were published in Iraq together with similar summaries obtained from stations maintained by the Air Ministry, Meteorological Service, Habbaniya.

Meteorological information continued to be supplied to civil aviation from Baghdad and Basra, the number of messages rising to 1,200 per month during the winter. As the volume of air traffic over Iraq continued to increase, difficulty was experienced in maintaining this part of the service, and the need for an extension of the existing wireless service was felt. As was only to be expected, the report contains little of purely scientific interest. Owing to the fact that air-conditioning engineers were constantly asking for data concerning the dust content of the air, the Director placed an order for an Owens settlement dust counter and for the necessary microscope for measuring the records.

\section{Lantern Slides}

THE cost of making lantern slides from illustrations may be materially reduced by using paper negatives, and Mr. G. H. Bell, of the Physiological Institute, Glasgow, gives an account in the December issue of the Journal of Scientific Instruments of a method he has found very satisfactory. He uses "Kodaline Paper Slow" exposed for three minutes at $f / 11$, the illustration being illuminated by four 100 -watt lamps placed just behind the camera lens. He develops with Kodaline developer and gets a pure black and white negative. He prints on gas-light lantern plates using a mask and giving an exposure of 8 seconds for a surface intensity of 65 foot-candles, uses an energetic developer and gets a slide with black lines on a perfectly clear background both for line diagrams and halftone illustrations.

\section{Drift of the Sedov}

The Northern Sea Route Administration of the U.S.S.R. is preparing for press a collection of articles and other material relating to the remarkable drift of 